\title{
Teaching EFL Academic Writing Through I-Search
}

\author{
Ignatius Harjanto \\ Widya Mandala Catholic University Surabaya, Indonesia
}

\begin{abstract}
EFL (English as a Foreign Language) graduate students are prepared and expected to be able to write good EFL academic papers. However, previous research and preliminary observation revealed that EFL graduate students still experience difficulties in grammar rules, idea development, referencing skills, and rhetoric. Academic writing problems have become a major challenge for many EFL students of graduate schools in Indonesia. To help graduate students write academic papers in English, the I-Search approach was employed to teach them academic writing. The I-Search approach appeared to help students to select topics, develop ideas, and find concrete support.
\end{abstract}

Writing papers in English is a challenge for EFL (English as a Foreign Language) students, and constructing academic papers in English is even more challenging. In general, EFL students, including the EFL graduate students of the master's program of a major university in Indonesia, have similar problems in writing English academic papers: finding ideas, rhetoric, and language (Bloor \& Bloor, 1993; Harjanto, 1999, 2001, 2012; Sa'Addedin, 1991). Despite student difficulties in writing academic papers in English, the master's program in Teaching English as a Foreign Language (TEFL) requires the students to attend the Academic Writing course in the first semester and to submit an academic paper about TEFL as the final project.

Considering that EFL academic writing proficiency is a very difficult skill for many EFL graduate students to master, the master's program in TEFL not only seeks to ensure that academic writing in English is intelligible, but that it is also accepted and, hopefully, acted upon. One of the teachers of the Academic Writing course attempted to motivate the students to write an academic paper by assigning an I-Search paper for their mid-semester project. This paper reports how the I-Search approach was integrated in the teaching of academic writing.

\section{What Is I-Search?}

Experiences in teaching English academic writing have shown that students undergo cyclical revision activities. This is in line with the idea that writing is not an instant skill but is gained through a process consisting of a series of sequenced stages (Clark, 2012). The I-Search approach is a process that includes four general parts: (1) selecting a topic (What I Already Know), (2) finding

Language Education in Asia, 2014, 5(1), 151-159. http://dx.doi.org/10.5746/LEiA/14/V5/I1/A12/Harjanto 
information (What I Want To Find Out), (3) using information (The Search), and (4) developing a final product (What I Learned). The stages of the I-Search approach are parallel to the "planning, drafting, and revising" sequence of the writing process (Clark, 2012, p. 7). According to Macrorie (1988), an I-Search paper is an alternative to the traditional research paper. Instead of working with topics of others (e.g., the teacher's topics), students select their own topics and work on meaningful projects of their own. They focus on their personal needs. The students' personal voices, including their own experiences on a certain topic, are usually the topic of an I-Search paper. The topic that they choose to write about could be one that they know or have experienced but want more deeply to understand, so the topic should not always be one that they are thoroughly familiar with. To understand deeply about the topic, the students have to browse the Internet, read written resources, discuss it with their friends, and interview experts.

\section{Why I-Search?}

Considering students' difficulties in writing academic papers in English, teachers need to seek a teaching approach that may motivate the students to learn academic writing. Indeed, students entering graduate school are faced with a range of adjustments to the ways they are expected to write academic papers in English (Hyland, 2009). Adjusting their prior rules and expectations in academic writing to the new ones requires a process of experience and is not always easy to do. Many students of the master's program graduating from non-English departments may be worried when dealing with academic writing. As argued by Friedrich (2008, p. 1), "writing is hard work," and academic English writing is quite possibly very hard for EFL students. To lessen the feeling of alienation (Hyland, 2009) in learning English academic writing, EFL students' personal experiences should be well considered. Thus, before writing on a serious academic topic, students are required to write about their own topic. A model of teaching English academic papers which deals with a personal need and requires students to take an active role of inquiry is the I-Search approach to writing.

A criticism of I-Search projects is that the assignments may not help students think critically (Luther, 2006). However, for EFL students, I-Search projects could be beneficial. As previously described, most students taking Academic Writing, especially those graduating from non-English departments, could be classified as novices. Novice students of EFL need to write meaningful papers for themselves before writing for others. This is in line with Macrorie's argument (1988) that the key to I-Search is that students work on meaningful projects, i.e., papers about topics they want to know more deeply.

\section{Course Context and Curriculum}

The master's program in TEFL admits multidisciplinary undergraduates. The students' English writing proficiency levels varied from intermediate to upper intermediate; those graduating from the English department (i.e., college level) had studied how to write academic paragraphs and papers, while those graduating from non-English departments practiced much less systematically writing academic papers in English. As a result, by the time the 23 students took the Academic Writing course, they came with their insufficient English writing experience and competence. Considering the students' background of writing papers in English, the course was designed to help the students to be able to write academic papers in English, such as final papers for courses, papers for journals and seminars, and a master's thesis. The course met once a week for 14 weeks: seven meetings for the first half of the semester and seven for the second. 


\section{Implementation of the I-Search: Tasks and Instructions}

The I-Search approach was not taught independently but integrated in the course of Academic Writing. The topics of the course were organized according to the syllabus, and an I-Search project was an integrated assignment in the first half of the semester. For seven meetings, the students learned theories of writing and practiced writing an I-Search paper.

In the first meeting, Part 1, What I Already Know, was introduced. The students started to learn how to find a topic from a broad theme (education). They explored topics which they might not be thoroughly familiar with but were interesting to them. To find a topic, the students were guided to think about something within the theme that they wanted to know more about. They were encouraged to search for ideas applicable to their lives in some way that they genuinely wanted to research. The guiding questions used to search for the topic were as follows:

1. Why is the issue important to my life?

2. What do I already know about my subject (theme / topic)?

In the second meeting, the students learned how to write a good academic paragraph as described by Oshima and Hogue (2006). They wrote a complete paragraph consisting of a topic sentence, supporting sentences, and a concluding sentence. Applying the structure of a paragraph, the students were assigned to write about the chosen I-Search topic (i.e., Part 2, What I Want To Find Out) outside of class. The students were also instructed to include reasons for writing about the chosen topic; they were ready to do this through using the guiding questions.

At the same time, in preparation for gathering the needed information, the students developed plans. In other words, in the third meeting, the students kept a journal of their research process, in addition to learning to write a good paragraph, containing values of unity, coherence, development, and completeness. In the classroom, the students learned and practiced writing a good paragraph, and outside the classroom they searched for sources by reading journals, books, and research reports and by browsing the Internet. They had to have a minimum of five written sources for their I-Search papers.

Part 3 of I-Search (The Search) was integrated in the fourth and fifth meetings. While learning to support a topic sentence with concrete details in the fourth meeting, the students searched for information. They learned to take notes from written sources to support their curiosity about their ISearch chosen topic and learned to quote and paraphrase from the original written texts. In the fifth meeting, the students learned how to write a data commentary on the data displayed in a table, graph, or figure (Swales \& Feak, 2009). The students wrote summary statements, highlighting statements, and discussions of implications. The exercises done in the classroom were practiced and reinforced outside the classroom. As homework, in addition to taking notes, the students were assigned to write a data commentary.

In the sixth and seventh meetings, the students learned to develop a paragraph into a paper (Arnaudet \& Barrett, 1990). At the same time, they kept writing about The Search and practicing Part 4, What I Learned. Outside the classroom, the students were assigned to write paragraphs of What I Learned, including paragraphs reflecting upon the entire search experience. The What I Learned paragraphs could be about the process of searching or what they learned about the topic. 


\section{Results and Discussion}

The theme of the I-Search papers was about education, which could be broadly divided into two topics: ELT and non-ELT. Examples of ELT topics were Translation in ELT, Learning English Vocabulary, and English Grammatical Errors; the non-ELT topics were Classroom Atmosphere to Enhance the Learning Quality, Edmodo (an online learning community) as Blended Learning, and The Effective Punishment: Types, Procedures, and Effects.

In general, the students' knowledge and experiences of the topics were written about well. The introduction to the topic was presented in Part 1 of the I-Search paper. Most of the students (18), were able to elaborate reasons for the topic with little difficulty; the rest (5) wrote a brief introduction with less clear reasons for choosing the topic. However, even those who might have experienced more difficulties in writing aspects of the topic wanted to know more than just how to write the background of the topic.

The topic and the controlling ideas of the I-Search paper were stated in the objective statements in Part 2. As with the introduction, 18 students did not have any difficulties in stating the objective of the I-Search paper. The following are examples of objective statements:

What is the effective non-physical punishment I can use in my classroom?

Can I teach English to the elementary and pre-intermediate EFL learners effectively by applying storytelling technique?

What kind of classroom management techniques should be implied in my formal and informal classroom? What is the teacher's role in managing the classroom? How can I understand ideal classroom for students?

With such clear objective statements, the writers were able to develop a plan for their research. Some students wrote their plans of research with few details, while more students wrote their plans with the steps of research, such as reading books, browsing the Internet, and interviewing experts.

Five students, including two students who did not provide clear reasons for choosing the topic, wrote unclear objective statements, such as, (1) "I will briefly summarize some of the ways RPGs [role-playing games] have been effectively employed in language classroom at different levels" and (2) "What should adults do in order to give the best nutrition and stimulation?" Objective Statement 1 did not tell about the topic learned, including the reasons for learning about the topic. Objective Statement 2 did not express the writer's curiosity about the topic. These objective statements did not contain personal questions and interest and could not guide the writers to investigate the topic.

Discussion of the topic was much influenced by the objective statement, the plan of research, and the number of sources. A clear objective statement with a clear plan of research was usually followed with a deeper discussion of the topic searched. Students who discussed almost all of the aspects of the topic read at least five sources, students who discussed many aspects of the topic read three to five sources, and students who discussed few aspects of the topic read less than three sources. 
The searched topic was presented with relevant concrete support taken from written sources, interviews with experts, or discussions with friends or teachers. Written sources mostly cited were books, followed by articles from the Internet. Journals and research reports were rarely cited. Usage of written sources was mostly done in paraphrases and quotations. Interviews with experts and discussions with friends and teachers were presented in quotations.

Regarding text citations, many students did it incorrectly and improperly. Twenty students experienced difficulties in citing written resources, although they felt that writing Part 3 was very easy. Incorrect citations could be related to (a) repetition of author's name for the same citation, (b) wrong writing of author's name and reference's title, (c) mistakes in the dates or pages (when necessary) of the source, or (d) date missing. The following are examples (errors shown in italics):

(a) Mamiq, in his book, explained that basically punishment is not for changing the characteristic of students but rather it focuses on the seen behavior which can be increased, reduced or modified (Mamiq, 2012).

(b) Stories are excellent opportunity for integrated skills practice including listening to stories which is based on "a positive attitude to not understanding everything" and "the skills of searching for meaning, predicting and guessing" (Wright $A$. 1995. Storytelling with Children).

(c) Kamil (2004) said, "Cooperative or collaborative learning can be considered both a strategy and a social organization that fosters learning. Many effective approaches to strategy instruction feature having students work on comprehension-related activities in small groups or pairs."

(d) According to Gardner, ... an intelligence includes the ability to relate and solve problems, create products or provide services that are valued within a culture or society.

Students who did not credit their sources and missed the dates and the pages of their written sources could be seen as plagiarizing. As was described by Hyland (2009), many students in this project seemed to experience difficulties in doing in-text citation.

Previous research (Harjanto, 1999, 2001, 2012) showed that serious problems in academic writing experienced by Indonesian students were idea development and rhetoric. In the case of idea development in this study, however, students might not have serious problems in developing their thesis / objective statements and topic sentences. The I-Search papers showed that the students developed their topic with relevant concrete support. Regarding rhetorical problems in this study, to some extent, most of them could be overcome. Such problems were partly solved because ISearch paper writing provided clear steps and text organization.

Both responses to a questionnaire (see Appendix) and Part 4 of the I-Search papers showed that most of the students thought that the I-Search approach was very helpful to develop ideas, present arguments, write standard academic papers, and review references. Almost $71 \%$ opined that they benefited greatly, almost $21 \%$ said they benefited moderately, and over $8 \%$ said they benefited slightly from writing I-Search paper exercises. None thought the exercises useless. Indeed, the 
students thought that they spent their time in a highly valuable way writing I-Search papers. Although the quality of the I-Search papers varied, none of the students thought they had wasted time writing them.

\section{Conclusion}

To help the students write English academic papers, the I-Search approach was introduced and integrated in the teaching of the course, Academic Writing. I-Search exercises were supplements to Academic Writing topics, which were not changed but enriched by the I-Search assignments. The students learned theories of writing and practiced them in the I-Search paper writing done outside the classroom.

In general, the students positively responded to the I-Search exercises. To some extent, they could solve their academic writing problems in terms of topic selection, idea development, referencing skills, and rhetoric. Of these four skills in the teaching of academic writing, more serious attention should be addressed to referencing skills. Rhetorical and idea development problems related to critical thinking should be further carefully identified and solved as well. This is imperative, for academic writing requires that students think critically.

\section{Author Note}

Ignatius Harjanto, Head of Master's Program in TEFL, the Graduate School of Widya Mandala Catholic University Surabaya, Indonesia.

Correspondence concerning this article should be addressed to Ignatius Harjanto, Jl. Dinoyo 42-44 Surabaya 60265, Indonesia. E-mail: ig.harjanto@gmail.com 


\section{References}

Arnaudet, M. L., \& Barrett, M. E. (1990). Paragraph development: A guide for students of English. Englewood Cliffs, NJ: Prentice-Hall.

Bloor, M., \& Bloor, T. (1993). Cultural expectations and socio-pragmatic failure. In P. Adams, B. Heaton, \& P. Howarrth (Eds.), Socio-cultural issues in English for academic purposes (pp. 112). London, England: Modern English Publications and The British Council.

Clark, I. L. (Ed.). (2012). Concepts in composition: Theory and practice in the teaching of writing. New York, NY: Routledge.

Friedrich, P. (Ed.). (2008). Teaching academic writing. East Sussex, England: Continuum. Harjanto, I. (1999). English academic writing features by Indonesian students of English (Unpublished dissertation). Universitas Negeri Malang, Malang, Indonesia.

Harjanto, I. (2001, November). The rhetorical problems in writing papers in English. Paper presented at the TEFLIN International Conference, Denpasar, Indonesia.

Harjanto, I. (2012). EFL student teachers' voices and behaviors on academic writing and teaching writing. Surabaya, Indonesia: Universitas Katolik Widya Mandala Surabaya.

Hyland, K. (2009). Academic discourse: English in a global context. London, England: Continuum. Luther, J. (2006). I-Searching in context: Thinking critically about the research unit. English Journal, 95(4), 65-73. http://dx.doi.org/10.2307/30047092

Macrorie, K. (1988). The I-Search paper. Portsmouth, NH: Boynton/Cook.

Oshima, A., \& Hogue, A. (2006). Writing academic English (4th ed.). London, England: Addison Wesley.

Sa'Addedin, M. A. A. M. (1991). Writing across language communities: The structure of Arabic text. In P. Adams, B. Heaton, \& P. Howarth (Eds.), Socio-cultural issues in English for Academic Purposes (Developments in English language teaching) (pp. 1-12). London, England: Modern English Publications and The British Council.

Swales, J. M., \& Feak, C. B. (2009). Academic writing for graduate students. Ann Arbor, MI: The University of Michigan. 


\section{Appendix}

\section{The Impact of I-Search on Academic Writing Skills}

Indicate the extent or degree of agreement to the following statements by placing a tick in the appropriate box.

1. How do you feel about writing your own topic in your I-Search paper?

$\square$ Very easy

$\square$ Moderately easy

$\square$ Slightly easy

$\square \quad$ Less easy

$\square \quad$ Not at all easy

2. How do you feel about writing a topic you want to know more?

$\square$ Very easy

$\square$ Moderately easy

$\square$ Slightly easy

$\square$ Less easy

$\square$ Not at all easy

3. How helpful is the application of I-Search paper in developing your own ideas?

$\square$ Very helpful

$\square$ Moderately helpful

$\square$ Slightly helpful

$\square$ Less easy

$\square$ Not at all helpful

4. How helpful is the application of I-Search paper in synthesizing others' ideas to support your own idea?

$\square$ Very easy

$\square$ Moderately easy

$\square$ Slightly easy

$\square$ Less easy

$\square \quad$ Not at all easy

5. How helpful is the application of I-Search paper in presenting your argument in a coherent manner?

$\square$ Very helpful

$\square$ Moderately helpful

$\square$ Slightly helpful

$\square$ Less helpful

$\square \quad$ Not at all helpful 
6. How helpful is the application of I-Search paper in writing a standard academic paper?

$\square$ Very helpful

$\square$ Moderately helpful

$\square$ Slightly helpful

$\square \quad$ Less helpful

$\square$ Not at all helpful

7. How helpful is the application of I-Search paper review references related to your topic?

$\square$ Very helpful

$\square$ Moderately helpful

$\square$ Slightly helpful

$\square$ Less helpful

$\square$ Not at all helpful

8. Of the four parts of I-Search paper, which one do you feel difficult to do?

$\square$ Part 1 - What I Already Know About My Topic

$\square$ Part 2 - What I Want to Find Out

$\square$ Part 3 - The Search

$\square$ Part 4-What I Learned

9. How do you benefit from I-Search paper writing exercises?

$\square$ Very beneficial

$\square$ Moderately beneficial

$\square$ Slightly beneficial

$\square \quad$ Less beneficial

$\square$ Not at all beneficial

10. What is your opinion on I-Search paper writing?

$\square$ Extremely needed for academic writing

$\square$ Very important for academic writing

$\square$ Important for academic writing

$\square$ Less important for academic writing 